\title{
Corticosteroid Injection for Treatment of de Quervain's Tenosynovitis: A Pooled Quantitative Literature Evaluation
}

\author{
Carlton A. Richie III, DO, and William W. Briner, Jr, MD
}

Background: There have been many approaches described to treat de Quervain's tenosynovitis, but no definite consensus emerges in the literature. We conducted a pooled quantitative literature evaluation to review the therapeutic studies in the English language to determine the various reported cure rates.

Methods: All citations in the MEDLINE and Ovid databases that addressed de Quervain's tenosynovitis were independently reviewed. Appropriate studies from the bibliographies of these articles were then obtained. Of the 35 articles on de Quervain's temosynovitis that were found in the modern literature, only seven allowed for comparison among potentially effective treatments. Studies were included if they evaluated or compared treatment options among patients and had defined criteria for diagnosis and successful treatment. These seven studies were descriptive, not comparative. In other words, each study reported the proportion of successful outcomes with different treatments, without a comparison to a specified control group. Four hundred fifty-nine wrists were subjected to one of several therapeutic modalities.

Results: There was an $83 \%$ cure rate with injection alone. This rate was much higher than any other therapeutic modality $(61 \%$ for injection and splint, $14 \%$ for splint alone, $0 \%$ for rest or nonsteroidal anti-inflammatory drugs).

Conclusion: It seems that injection alone is the best therapeutic approach to de Quervain's tenosynovitis. (J Am Board Fam Pract 2003;16:102-6.)

In 1895, Fritz de Quervain, a Swiss surgeon, first described tenosynovitis within the first dorsal wrist extensor compartment at the radial styloid. The usual complaint was pain in the region of the wrist joint. De Quervain's tenosynovitis is a painful and often disabling condition that is mainly observed in workers who perform repetitive manual tasks, wrestlers, and bowlers. Since the original description, a variety of methods have been recommended to treat this tenosynovitis, which involves the abductor pollicis longus and extensor pollicis brevis (Figure 1a and Figure 1b). The purpose of this study was to define the most effective therapeutic approach to this condition based on a consensus standard from the available literature, if one existed.

\section{Methods}

All citations in the MEDLINE and Ovid databases that addressed de Quervain's tenosynovitis were

Submitted, revised, 10 July 2002.

From the Lutheran General Hospital Sports Medicine Center (CAR, WWB), Park Ridge, Ill. Address reprint requests to Carlton A. Richie III, DO, 5030 South Mill Ave, Suite D-12, Tempe, AZ 85282. reviewed. Appropriate studies from the bibliographies of these articles were obtained. Of the 35 articles on de Quervain's tenosynovitis that were found, only seven allowed for comparison among potentially effective treatments. Studies were included in the efficacy analysis if they evaluated or compared treatment options among patients and had defined criteria for both diagnosis and successful treatment. It should be noted that each of the analyzed studies used identical criteria for diagnosis and the definition of treatment efficacy. Specifically, the diagnostic criteria were (1) pain at the radial wrist, (2) tenderness at the first dorsal wrist extensor compartment, and (3) a positive Finkelstein test (Figure 2). Treatment efficacy was defined as the absence of all of these criteria subsequent to intervention.

All seven studies were descriptive, not comparative. Each study reported the proportion of successful outcomes with different treatments without comparison to a specified control group. Across the seven selected studies, 459 wrists were subjected to one of several therapeutic modalities. The most frequently used modality was injection alone (Fig- 


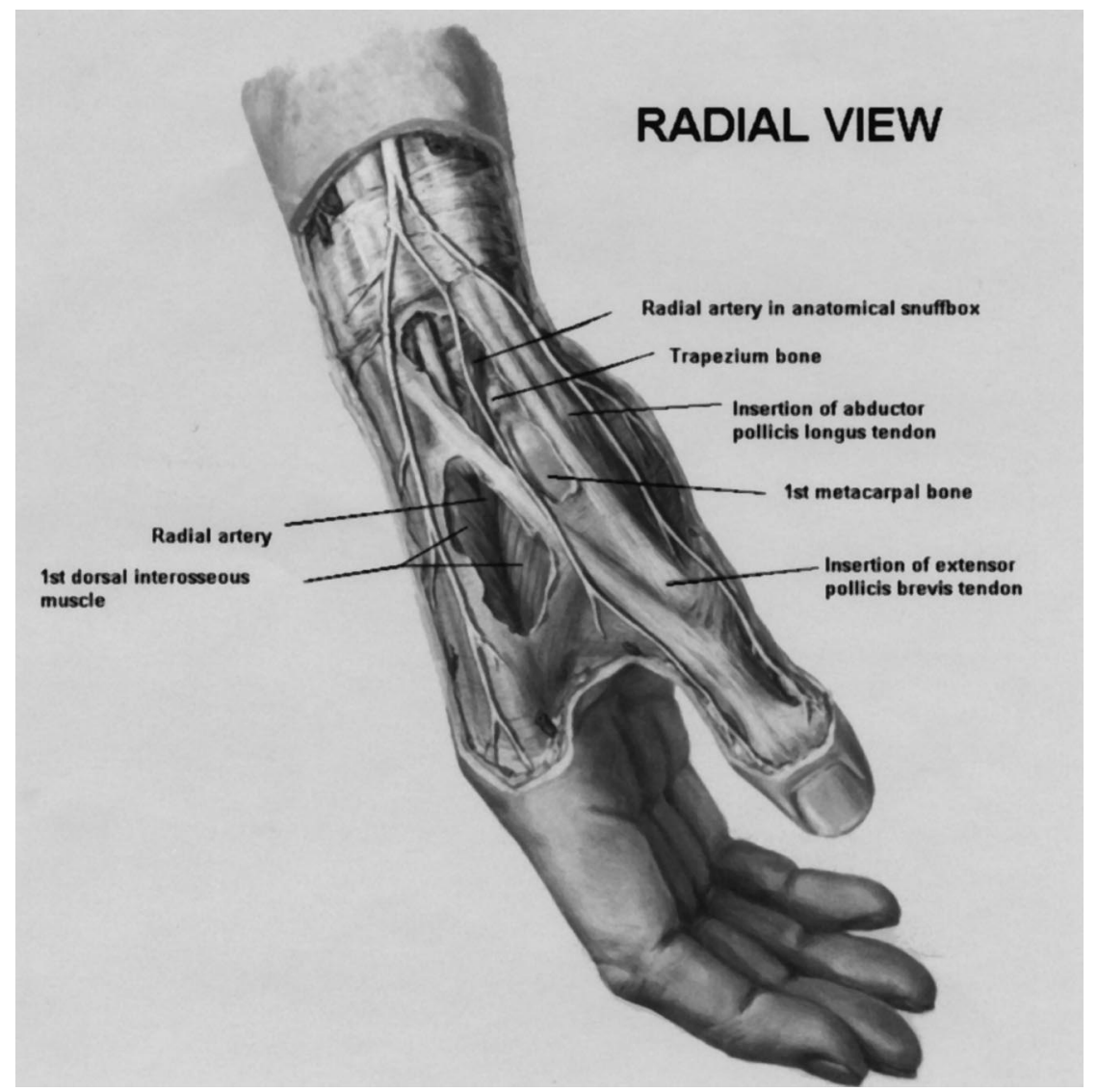

Figure 1a. Anatomy of the first dorsal wrist extensor compartment: radial view.

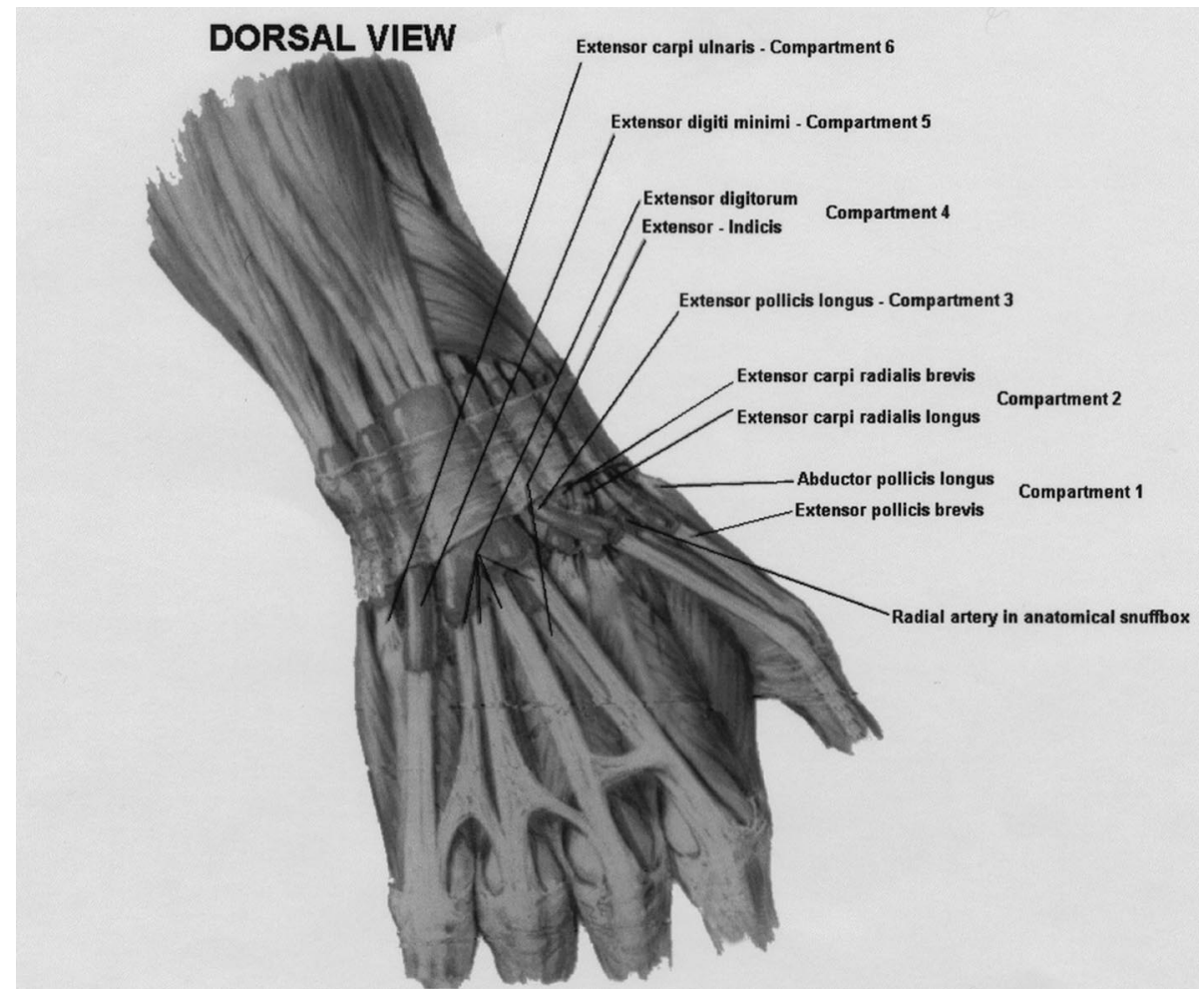

Figure 1b. Anatomy of the first dorsal wrist extensor compartment: dorsal view. 

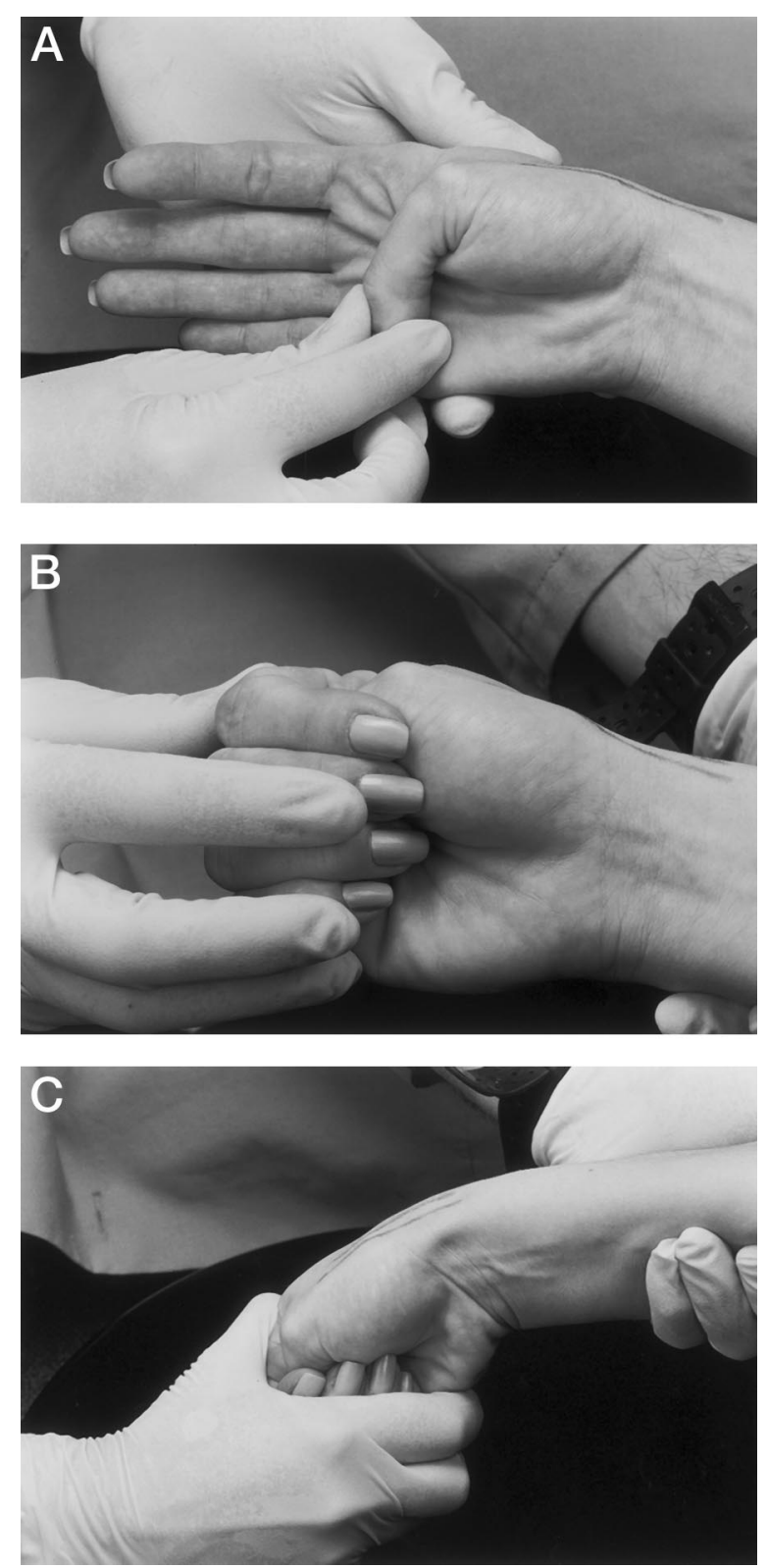

Figure 2. Demonstration of Finkelstein's test.

ure 3). Relevant characteristics of the included studies are displayed in Table 1.

\section{Results}

When subjects from the seven relevant studies were pooled for a range of outcomes, $83 \%$ of the 226 wrists that received injection alone were symptomatically cured, $61 \%$ of the 101 wrists that received injection and splint immobilization were cured, and $14 \%$ of those who received splinting only were cured. Rest alone $(\mathrm{n}=17)$ and nonsteroidal antiinflammatory drugs alone $(n=39)$ did not result in

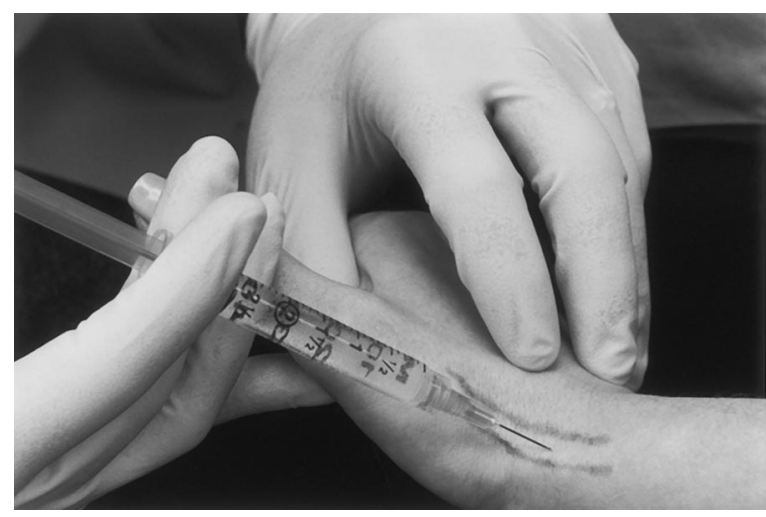

Figure 3. Injection of the first dorsal wrist extensor compartment.

any symptomatic cures (Table 2). Time of assessment of therapeutic efficacy was 1 to 2 weeks with a time range of 0.25 to 84 months.

\section{Discussion}

The relevant published data show that injection alone, with an $83 \%$ cure rate, was the most effective treatment for this condition. Injection is simple, cost-effective, and without serious side effects. There were no tendon ruptures among 459 wrists in this analysis, 327 of which were injected during an average follow-up of 9.6 months. There were differences in the type of corticosteroid injected, and there might have been minor differences in injection technique used by the investigators in the seven studies. Even so, the effect of injection alone as the most successful treatment option seemed to stand up across the studies.

The combination of injection and splinting actually resulted in a greater percentage of treatment failure $(39 \%)$ than injection alone (17\%). Perhaps this outcome is due to Wolff's law as applied to tendons (tissue heals or remodels in accordance with stresses placed upon it). The mean ages for the subject groups in the 7 studies varied between 38.0 and 49.4 years, similar to the age distribution during which most lateral epicondylitis and some other overuse syndromes occur. ${ }^{8}$ Perhaps the effects of overuse begin to overwhelm the healing capacity of connective tissue in the fourth and fifth decade in some persons. Findings at surgery have led some investigators to note that injection failure can occur secondary to anatomic variation within the first extensor compartment. One author ${ }^{2}$ found a separate synovial compartment containing the extensor 
Table 1. Selected Characteristics of Seven Studies that Examined the Treatment of de Quervain's Tenosynovitis.

\begin{tabular}{|c|c|c|c|c|c|c|c|}
\hline $\begin{array}{l}\text { Study } \\
\text { Characteristics }\end{array}$ & $\begin{array}{l}\text { Weiss et al }^{1} \\
1994\end{array}$ & $\begin{array}{c}\text { Harvey et al } \\
1990\end{array}$ & $\begin{array}{c}\text { Anderson et al } \\
1991\end{array}$ & $\begin{array}{c}\text { Witt et al }{ }^{4} \\
1991\end{array}$ & $\begin{array}{c}\text { McKenzie }^{5} \\
1972\end{array}$ & $\begin{array}{c}\text { Zingas et } \mathrm{al}^{6} \\
1998\end{array}$ & $\begin{array}{c}\text { Christie }^{7} \\
1955\end{array}$ \\
\hline $\begin{array}{l}\text { Women's } \\
\text { wrists }\end{array}$ & 80 & 70 & 50 & 64 & 25 & 12 & 16 \\
\hline Men's wrists & 13 & 12 & 5 & 19 & 5 & 7 & 4 \\
\hline Bilateral & 0 & 0 & 1 & 4 & 0 & 0 & 0 \\
\hline $\begin{array}{l}\text { Mean age, } \\
\text { years (range) }\end{array}$ & $38(17-72)$ & $45(16-83)$ & $47(21-80)$ & $44(16-75)$ & $49.5(25-74)$ & $39(24-63)$ & $46(18-74)$ \\
\hline Demographics & $\begin{array}{l}\text { No difference } \\
\text { in treatment } \\
\text { success when } \\
\text { comparing } \\
\text { sex, hand } \\
\text { dominance, } \\
\text { age, or } \\
\text { duration of } \\
\text { symptoms }\end{array}$ & $\begin{array}{l}\text { Women with } \\
\text { infants and } \\
\text { small } \\
\text { children, hand } \\
\text { dominance, } \\
\text { secretary, } \\
\text { nursing } \\
\text { occupation }\end{array}$ & $\begin{array}{l}\text { Housework, } \\
\text { clerical }\end{array}$ & $\begin{array}{l}\text { No association } \\
\text { found } \\
\text { between sex, } \\
\text { hand } \\
\text { dominance, } \\
\text { age, or } \\
\text { duration }\end{array}$ & Not noted & $\begin{array}{l}\text { Homemaker, } \\
\text { barber, } \\
\text { salesperson }\end{array}$ & $\begin{array}{l}\text { Tailor, cutter, } \\
\text { seamstress, } \\
\text { poster artist }\end{array}$ \\
\hline $\begin{array}{r}\text { Criteria for } \\
\text { diagnosis }\end{array}$ & $\begin{array}{l}\text { Pain at radial } \\
\text { wrist, tender } \\
\text { over } 1 \text { st } \\
\text { dorsal } \\
\text { compartment, } \\
\text { Finkelstein's } \\
\text { test }\end{array}$ & $\begin{array}{l}\text { Pain at radial } \\
\text { wrist, tender } \\
\text { over 1st } \\
\text { dorsal } \\
\text { compartment, } \\
\text { Finkelstein's } \\
\text { test }\end{array}$ & $\begin{array}{l}\text { Pain at radial } \\
\text { wrist, tender } \\
\text { over 1st } \\
\text { dorsal } \\
\text { compartment, } \\
\text { Finkelstein's } \\
\text { test }\end{array}$ & $\begin{array}{l}\text { Pain at radial } \\
\text { wrist, tender } \\
\text { over 1st } \\
\text { dorsal } \\
\text { compartment, } \\
\text { Finkelstein's } \\
\text { test }\end{array}$ & $\begin{array}{l}\text { Pain at radial } \\
\text { wrist, tender } \\
\text { over } 1 \text { st } \\
\text { dorsal } \\
\text { compartment, } \\
\text { Finkelstein's } \\
\text { test }\end{array}$ & $\begin{array}{l}\text { Pain at radial } \\
\text { wrist, tender } \\
\text { over 1st } \\
\text { dorsal } \\
\text { compartment, } \\
\text { Finkelstein's } \\
\text { test }\end{array}$ & $\begin{array}{l}\text { Pain at radial } \\
\text { wrist, tender } \\
\text { over 1st } \\
\text { dorsal } \\
\text { compartment, } \\
\text { Finkelstein's } \\
\text { test }\end{array}$ \\
\hline $\begin{array}{r}\text { Exclusion } \\
\text { criteria }\end{array}$ & Not noted & $\begin{array}{l}\text { Previous } \\
\text { treatment }\end{array}$ & $\begin{array}{l}\text { No previous } \\
\text { steroid } \\
\text { injection } \\
\text { within past } 6 \\
\text { months }\end{array}$ & $\begin{array}{l}\text { Rheumatoid } \\
\text { arthritis }\end{array}$ & Not performed & $\begin{array}{l}\text { Previous wrist } \\
\text { surgery, } \\
\text { previous 1st } \\
\text { extensor } \\
\text { compartment } \\
\text { injection, } \\
\text { rheumatoid } \\
\text { arthritis in } \\
\text { pregnancy }\end{array}$ & $\begin{array}{l}\text { No obvious } \\
\text { preceding } \\
\text { trauma }\end{array}$ \\
\hline $\begin{array}{c}\text { Duration of } \\
\text { symptoms, } \\
\text { mo (range) }\end{array}$ & $7(0.25-36)$ & $3.2(0.75-14)$ & $4.4(1-24)$ & $5.35(0.5-18)$ & $1.25-9$ & $3.9(1-11)$ & $8(1-36)$ \\
\hline $\begin{array}{l}\text { Injection } \\
\text { medicine } \\
\text { used }\end{array}$ & $\begin{array}{l}1 \mathrm{cc} \\
\text { betamethasone, } \\
1 \mathrm{cc} 1 \% \\
\text { lidocaine }\end{array}$ & $\begin{array}{l}\text { Hydrocortisone } \\
\text { acetate or } \\
\text { methyl } \\
\text { prednisolone } \\
\text { acetate, } \\
\text { "local" } \\
\text { anesthetic }\end{array}$ & $\begin{array}{l}\text { Methyl- } \\
\text { prednisolone, } \\
80 \mathrm{mg}, 1 \% \\
\text { Xylocaine } \\
1.5 \mathrm{cc}\end{array}$ & $\begin{array}{l}40 \mathrm{mg} \text { methyl- } \\
\text { prednisolone, } \\
1 \% \text { lidocaine } \\
1 \mathrm{cc}\end{array}$ & $\begin{array}{l}25 \mathrm{mg} \\
\text { hydrocortisone, } \\
2 \% \text { lidocaine } \\
1 \mathrm{cc}\end{array}$ & $\begin{array}{l}6 \mathrm{mg} \\
\text { Celestone, } \\
1 \% \text { lidocaine } \\
3 \mathrm{cc}\end{array}$ & $\begin{array}{l}25 \mathrm{mg} \\
\text { hydrocortisone } \\
\text { acetate, } 2 \% \\
\text { procaine } 1 \mathrm{cc}\end{array}$ \\
\hline One injection & 42 & 45 & 33 & 0 & 24 & 19 & 16 \\
\hline $\begin{array}{l}\text { Repeated } \\
\text { injection }\end{array}$ & 0 & 7 & 14 & 0 & 5 & 0 & 4 \\
\hline $\begin{array}{l}\text { Injection and } \\
\text { splint }\end{array}$ & 14 & 0 & 0 & 87 & 0 & 0 & 0 \\
\hline $\begin{array}{l}\text { Thumb spica } \\
\text { splint }\end{array}$ & 37 & 0 & 39 & 0 & 0 & 0 & 0 \\
\hline NSAID & 0 & 0 & 39 & 0 & 0 & 0 & 0 \\
\hline Rest & 0 & 0 & 17 & 0 & 0 & 0 & 0 \\
\hline $\begin{array}{l}\text { Definition of } \\
\text { success }\end{array}$ & $\begin{array}{l}\text { Absence of } \\
\text { diagnostic } \\
\text { criteria }\end{array}$ & $\begin{array}{l}\text { Absence of } \\
\text { diagnostic } \\
\text { criteria }\end{array}$ & $\begin{array}{l}\text { Absence of } \\
\text { diagnostic } \\
\text { criteria }\end{array}$ & $\begin{array}{l}\text { Absence of } \\
\text { diagnostic } \\
\text { criteria }\end{array}$ & $\begin{array}{l}\text { Absence of } \\
\text { diagnostic } \\
\text { criteria }\end{array}$ & $\begin{array}{l}\text { Absence of } \\
\text { diagnostic } \\
\text { criteria }\end{array}$ & $\begin{array}{l}\text { Absence of } \\
\text { diagnostic } \\
\text { criteria }\end{array}$ \\
\hline Side effects & Not noted & $\begin{array}{l}2 \text { nontender } \\
\text { nodules, } 2 \\
\text { skin color } \\
\text { changes }\end{array}$ & $\begin{array}{l}\text { Skin color } \\
\text { changes and } \\
\text { fat atrophy } \\
=16 \text {, flare } \\
=5\end{array}$ & None & None & None & $\begin{array}{l}\text { Superficial } \\
\text { thrombo- } \\
\text { phlebitis (1) }\end{array}$ \\
\hline Failure & $\begin{array}{l}45 \text { (underwent } \\
\text { surgery) }\end{array}$ & $\begin{array}{l}11 \text { (6 had } 2 \\
\text { injections, } 5 \\
\text { had } 1 \\
\text { injection) }\end{array}$ & 5 & $\begin{array}{c}30 \text { (within } 3 \\
\text { months) }\end{array}$ & 1 & $\begin{array}{l}8 \text { (3 had } \\
\text { surgery, } 5 \\
\text { had return of } \\
\text { criteria) }\end{array}$ & 1 \\
\hline $\begin{array}{l}\text { Follow-up, mo } \\
\text { (range) }\end{array}$ & $4,13(6-14)$ & $0.5,20(0.25-84)$ & $1.5,48(6-71)$ & $18(12-30)$ & $0.5,1,3,18$ & 1,3 & 3.5 \\
\hline
\end{tabular}

NSAID - nonsteroidal antiinflammatory drug. 
Table 2. Pooled Outcomes of Five Treatments for de Quervain's Tenosynovitis.

\begin{tabular}{lcc}
\hline $\begin{array}{l}\text { Treatment } \\
\text { Modality }\end{array}$ & No. & Percent Cured \\
\hline Injection & 226 & 83 \\
Injection and splint & 101 & 61 \\
Splint alone & 76 & 14 \\
Rest alone & 17 & 0 \\
Nonsteroidal & 39 & 0 \\
$\quad$ antiinflammatory & & \\
\hline drugs & & \\
\hline
\end{tabular}

pollicis brevis at surgery in $91 \%$ of cases that failed one or more injections. Cadaveric dissection studies have shown that this variant is present in $40 \%$ of wrists. ${ }^{4}$ These authors suggest that surgery might be considered in cases where two well-placed injections have failed, and all diagnostic criteria are still present after 4 months of symptoms. ${ }^{2,4}$ There could also have been a bias in favor of surgical treatment, especially among subjects in the first study, ${ }^{1}$ in which 45 of 93 wrists (48.4\%) were eventually operated on (a much higher percentage than that reported in the other studies).

\section{Conclusions}

It seems that injection alone is the best therapeutic approach to de Quervain's tenosynovitis. The pri- mary care physician who understands the anatomy of the first dorsal wrist extensor compartment can readily perform this procedure. In the overwhelming majority of cases, this treatment is likely to be definitive.

\section{References}

1. Weiss AP, Akelman E, Tabatabai M. Treatment of de Quervain's disease. J Hand Surg [Am] 1994;19: 595-8.

2. Harvey FJ, Harvey PM, Horsley MW. De Quervain's disease: surgical or nonsurgical treatment. J Hand Surg [Am] 1990;15:83-7.

3. Anderson BC, Manthey R, Brouns MC. Treatment of De Quervain's tenosynovitis with corticosteroids. A prospective study of the response to local injection. Arthritis Rheum 1991;34:793-8.

4. Witt J, Pess G, Gelberman RH. Treatment of de Quervain tenosynovitis. J Bone Joint Surg Am 1991; 73:219-22.

5. McKenzie JM. Conservative treatment of de Quervain's disease. Br Med J 1972,4:659-60.

6. Zingas C, Failla JM, Van Holsbeeck M. Injection accuracy and clinical relief of de Quervain's tendinitis. J Hand Surg [Am] 1998;23:89-96.

7. Christie BG. Local hydrocortisone in De Quervain's disease. Br Med J 1955;1:1501-3.

8. Pascarelli EF, Hsu YP. Understanding work-related upper extremity disorders: clinical findings in 485 computer users, musicians, and others. J Occup Rehabil 2001;11:1-21. 